\title{
Vegan Venture: Mission Drives Success for Restaurant Chain
}

\section{Donna De Carolis (Drexel University)}

\section{KEYWORDS: Accommodation \& Food Services, Management, Leadership, Women.}

Nicole Marquis, founder of Philadelphia's HipCityVeg vegan restaurant chain, strongly believes in a holistic approach to living and managing a venture. In this interview with EIX Editor Donna De Carolis, Marquis talks about how her commitment to veganism shapes her own sense of well-being and helps her run a successful business. "When you are working towards a greater good," she says, "there's an incredible energy behind you that keeps you going through the challenges."

\section{Read More:}

Advice, Best Practices and Inspiration for Women Entrepreneurs(https://eiexchange.com/women)

Additional search terms: women, feminism, female founders, women business owners, glass ceiling, restaurants, vegan, vegans, restaurants for vegans, mission-driven startups 